\title{
Evaluation of Curcuma longa L. Water Extracts as Beauty Food Materials in B16F10 and Human Skin Fibroblasts
}

\author{
Hyeong-Jin Ju ${ }^{1}$, Seong-Ae Lee ${ }^{1}$, Ryeong-Hyeon Kim ${ }^{1}$, Bu-Duk Park ${ }^{2}$, Gyo-Nam Kim ${ }^{1 *}$ \\ ${ }^{1}$ Department of Food, Nutrition and Biotechnology, Kyungnam University, Changwon-si, Gyeongsangnam-do, Korea \\ ${ }^{2}$ Balhyochon, Gyeongsan-si, Gyeongsangbuk-do, Korea
}

\author{
*Corresponding author: Gyo-Nam Kim, \\ Department of Food, Nutrition and \\ Biotechnology, Kyungnam University, 7 \\ Kyungnamdaehak-ro, Masanhappo-gu, \\ Changwon-si, Gyeongsangnam-do 51767, Korea \\ Tel.: +82552496330 \\ Fax: +82 5059992171 \\ Email: gnkim@kyungnam.ac.kr
}

Received March 8, 2017

Revised April 17, 2017

Accepted April 18, 2017

Published June 30, 2017

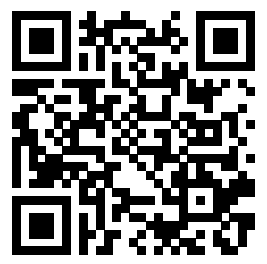

\begin{abstract}
Purpose: To test whether water extracts of Curcuma longa L. (CLE) have the potential as beauty food materials, the inhibitory effects of CLE on melanin accumulation in B16F10 cells and regulatory effects of CLE on the skin fibril-related genes in human skin fibroblasts (HSFs) were examined in this study. Methods: Thiazolyl blue tetrazolium bromide (MTT) assay was used to evaluate the cytotoxicity of CLE in B16F10 or HSFs. Inhibitory effects of CLE on the melanin accumulation were evaluated by B16F10-eluted melanin content and image analysis. The expressions of skin fibril-related genes such as procollagen $1 \alpha 1$, procollagen $1 \alpha 2$, and elastin in HSFs were evaluated by reverse transcription-polymerase chain reaction (RT-PCR) analysis. Results: Based on the cytotoxicity results, the concentrations of CLE were confirmed under $400 \mu \mathrm{g} / \mathrm{mL}$ in both B16F10 and HSFs. The cytotoxicity of B16F10 cells with CLE for $24 \mathrm{~h}$ was confirmed and CLE up to $400 \mu \mathrm{g} / \mathrm{mL}$ were used. The CLE from 50 to $400 \mu \mathrm{g} / \mathrm{mL}$ significantly inhibited melanin accumulation in B16F10 cells. The HSFs treated with CLE showed up-regulated skin fibril-related genes. Conclusion: Those results show that CLE has benefits with skin-whitening and upregulation of skin fibril-related genes, which means it could be used as an ingredient in beauty foods and/or cosmetic materials.
\end{abstract}

Keywords: Curcuma longa L., Skin, Melanin, Elasticity, Beauty food

\section{Introduction}

피부는 크게 표피, 진피, 그리고 피하지방층으로 구성되어 있고, 이 중에서 표피는 피부의 가장 바깥쪽에 위치하며 다양한 외부환경 에 의해 영향을 많이 받는 조직이다. 피부는 각질세포로 구성된 각 질층에 의해 자외선 등을 비롯한 다양한 외부환경에 대한 방어 역 할을 하고(Fisher et al., 2002; Kim et al., 2014), 체내의 수분과 전해질의 손실을 예방하는 역할을 한다(Elias, 1983; Feingold et al., 2007). 멜라닌은 표피의 하부층과 진피 사이에서 형성되며, 적 정한 수준으로 존재할 때 자외선 등 외부의 자극에 대해 세포를 보 호하는 이로운 역할을 수행한다. 또한 멜라닌은 형성되는 양과 종 류에 따라 피부색, 눈동자, 그리고 머리카락 등의 색을 결정짓는 요 인이기도 하다(Hill et al., 1997). 하지만 과도하거나 비정상적인 멜 라닌 형성은 피부의 과 색소침착, 주근깨, 피부염증, 그리고 피부암 등을 야기한다고 알려져 있다(Urabe et al., 1994).
피부는 다양한 외부 스트레스 요인에 노출되어 있으며 그 중 표 피는 가장 바깥쪽에 위치함으로 특히 자외선 등에 의해 노화가 진 행된다(Chung, 2003; Rittié \& Fisher, 2002). 피부의 노화에는 다 양한 생물학적, 화학적, 물리적인 원인이 있는데 그 중에서도 특 히 지속적인 자외선의 노출로 인한 피부노화를 광노화라고 한다 (Fisher et al., 2002; Wenk et al., 2001). 광노화가 장기간 진행되 면 피부의 수분이 손실되어 피부가 거칠어지게 됨은 물론 피부탄력 의 감소로 인해 피부장벽이 손상되어 주름을 발생시키므로, 건강 한 피부의 유지를 위해 피부의 탄력을 유지시키는 것은 중요하다 (Fisher et al., 1997; Seite et al., 2006).

피부건강을 위협하는 탄력저하에 의한 주름의 발생은 피부의 진 피조직의 변형에 의해 일어난다(Baumann, 2007). 진피층을 구성 하는 단백질에는 대표적으로 콜라겐(collagen), 엘라스틴(elastin) 등이 있다. 콜라겐은 진피층의 $90 \%$ 이상을 차지하고 있어 콜라겐 의 과도한 분해 및 소실은 피부의 탄력을 저하시킨다. 이전의 연 
구에 따르면 외부자극에 의해 감소된 프로콜라겐(procollagen) 에 의해 콜라겐의 분해를 증가시킴으로 탄력이 감소되고 주름 형성이 촉진되어 결과적으로 피부노화를 일으킨다고 알려져 있 다(Brenneisen et al., 2002; Ito et al., 2010; Shephard et al., 2004). 따라서 이러한 콜라겐 및 엘라스틴 단백질을 유지하는 것은 피부의 건강한 탄력 및 주름 형성을 억제하는데 중요하다(Davies, 1987; Fantone \& Ward, 1982). 최근 경제수준의 증가 등으로 인해 사람들의 피부건강에 대한 관심이 남녀 불문하고 크게 증가하고 있 는 추세이다(Yaar \& Gilchrest, 1998). 먹어서 아름다워진다는 이 너뷰티(inner beauty) 시장의 급성장은 화장품 산업의 발달과 함께 식품산업에서도 중요하게 다뤄지고 있으며, 이와 관련하여 이너뷰 티 소재를 탐색하고자 하는 다양한 연구가 수행되고 있다(Royer et al., 2013).

본 연구에서 사용한 울금(Curcuma longa L.)은 커큐미노이드 (curcuminoid)라는 생리 활성 성분이 널리 알려져 있으며, 이와 관 련된 다양한 연구가 보고되었다(Ammon \& Wahl, 1991; Revathy et al., 2011). 울금의 생리학적 활성과 관련하여 다양한 보고가 있었으 나(Shon \& Kim, 2014), 피부건강 및 미용기능식품 소재로서의 울금 에 대한 평가는 상대적으로 미비한 실정이다. 따라서 본 연구에서는 $\mathrm{B} 16 \mathrm{~F} 10$ 세포에서 울금 추출물의 멜라닌 합성 저해를 통한 미백 활 성을 평가하고, HSFs 세포에서 울금 추출물 처리가 피부의 탄력과 연관된 유전자인 procollagen1a1, procollagen $1 \alpha 2$, elastin의 발현에 미치는 영향을 알아보았다. 이러한 결과를 바탕으로 울금 추출물이 미용기능성식품 소재로서의 이용 가능성에 고찰하고자 한다.

\section{Methods}

\section{1. 실험 재료}

본 실험에 사용된 국내 진도산 CLE는 (주)삼진내추럴(Korea)에 서 구입하여 사용하였다. CLE의 제조는 $1 \mathrm{~kg}$ 의 울금을 증류수 10 $\mathrm{L}$ 에 희석하여 $100 \pm 5^{\circ} \mathrm{C}$ 에서 가열 및 추출한 후 1 차 매쉬망 및 2 차 필터를 통해 여과하였으며 최종 $65 \mathrm{brix}$ 에 농축을 종료하여 제조되 었다. MTT, 3-isobutyl-1-methylxanthine (IBMX), chloroform 은 Sigma-Aldrich (USA)에서 구매하였으며, B16F10 및 HSFs 세포의 배양 등에 사용된 Dulbecco's modified Eagle's medium (DMEM), antibiotics (penicillin-streptomycin mixture), fetal bovine serum (FBS)은 Welgene (Korea)에서 구입하여 사용하였다. 그리고 isopropanol, dimethyl sulfoxide (DMSO) 는 Junsei Chemical (Japan)에서 구입하였다. RT-PCR에 사 용된 TRIzol ${ }^{\circledR}$ 은 Invitrogen ${ }^{\mathrm{Tx}}$, Thermo Fisher Scientific (USA) 에서, AccuPower ${ }^{\circledR}$ CycleScript RT PreMix는 Bioneer (Korea) 에서, agarose는 Bio-Rad Laboratories (USA), 그리고 RNasefree water는 Welgene에서 구입하여 사용하였다. 본 연구에 사용

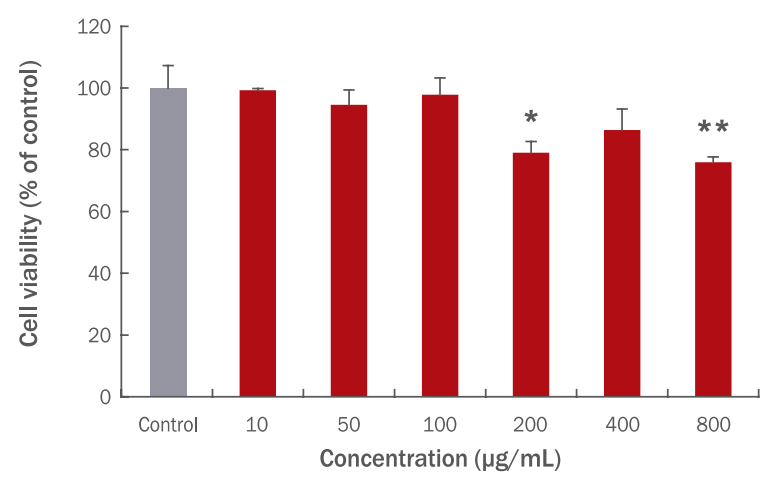

Figure 1. Effects of CLE on B16F10 viability.

B16F10 cells were treated with 10, 50, 100, 200, 400, and $800 \mu \mathrm{g} / \mathrm{mL}$ CLE for $24 \mathrm{~h}$ and cell viability was evaluated by MTT assay at $570 \mathrm{~nm}$ using the microplate reader. Statistical analysis was performed at ${ }^{*} p<0.05$ and ${ }^{* *} p<0.01$ by t-test. The 200 and $800 \mu \mathrm{g} / \mathrm{mL}$ CLE affected to the cell viability of B16F10. Further experiment was conducted under $400 \mu \mathrm{g} / \mathrm{mL}$ of CLE. CLE, water extracts of Curcuma longa L.; Control, CLE untreated group; MTT, thiazolyl blue tetrazolium bromide.

된 B16F10 세포는 한국세포주은행(Korea)에서, HSFs는 American Type Culture Collection (USA)에서 분양 받아 이용하였다.

\section{2. 세포독성 평가}

$\mathrm{B} 16 \mathrm{~F} 10$ 및 $\mathrm{HSFs}$ 세포에서 $\mathrm{CLE}$ 의 세포독성을 평가하기 위해 MTT assay를 실시하였다. 세포는 $12-w e l l$ plate에 $1 \times 10^{5}$ cells/ $\mathrm{mL}$ 농도로 $1 \mathrm{~mL}$ 씩 분주하고 $37^{\circ} \mathrm{C}, 5 \% \mathrm{CO}_{2}$ 환경에서 배양하였 다. $100 \%$ 포화상태(confluent)가 되면 B16F10 세포에 10, 50, 100, $200,400,800 \mu \mathrm{g} / \mathrm{mL}$ 의 농도로 $\mathrm{CLE}$ 를 $24 \mathrm{~h}$ 동안 처리한 후, phosphate buffered saline (PBS)에 녹여진 MTT 시약을 최종 200 $\mu \mathrm{g} / \mathrm{mL}$ 로 $\mathrm{DMEM}$ 배지에 희석하여 $1 \mathrm{~mL}$ 씩 분주하고 추가로 $37^{\circ} \mathrm{C}$ 에서 배양하였다(B16F10 $30 \mathrm{~min}$; HSFs 1 h). 반응이 끝나면 배지 를 완전히 제거하고 $\mathrm{DMSO}$ 를 각 well 마다 첨가하여(B16F10 $400 \mu$ $\mathrm{L}$; HSFs $300 \mu \mathrm{L}$ ), 보라색의 formazan을 용해한 후 96-well plate 에 각각 분주하였고(B16F10 $50 \mu \mathrm{L}$; HSFs $100 \mu \mathrm{L})$, microplate reader (VersaMax; Molecular Devices, USA)를 사용하여 $570 \mathrm{~nm}$ 의 흡광도에서 측정하였다. CLE를 처리하지 않은 $\mathrm{B} 16 \mathrm{~F} 10$ 및 $\mathrm{HSFS}$ 세포의 흡광도 값을 대조군으로 하여 세포독성을 분석하였다.

\section{3. 멜라닌 생성 저해 측정}

$\mathrm{CLE}$ 가 $\mathrm{B} 16 \mathrm{~F} 10$ 세포의 멜라닌 생성에 어떠한 영향을 미치는지 알아보기 위하여 세포를 $12-w e l l$ plate에 $1 \times 10^{5}$ cells $/ \mathrm{mL}$ 의 농도로 $1 \mathrm{~mL}$ 씩 분주한 후, $\mathrm{B} 16 \mathrm{~F} 10$ 세포가 $70 \%$ 포화상태가 되었을 때 500 $\mu \mathrm{M} \mathrm{IBMX}$ 를 $72 \mathrm{~h}$ 동안 처리하여 멜라닌을 유도하고 CLE를 농도별 로 $10,50,100,200,400 \mu \mathrm{g} / \mathrm{mL}$ 를 처리하여 $37^{\circ} \mathrm{C}, 5 \% \mathrm{CO}_{2}$ 환경에 서 배양하였다. 멜라닌 유도를 시키지 않은 $\mathrm{B} 16 \mathrm{~F} 10$ 세포는 control 
A

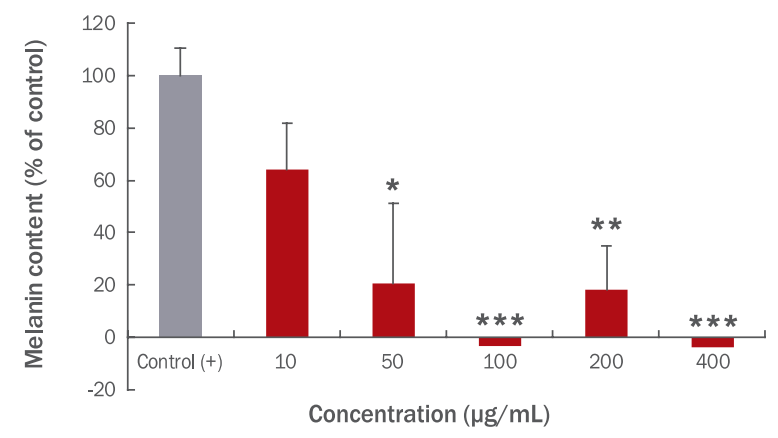

B
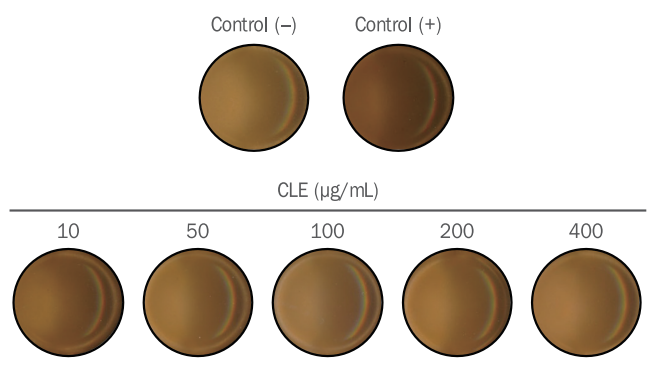

Figure 2. Inhibitory effects of CLE on melanin accumulation of B16F10 induced by IBMX.

To confirm the effects of CLE on inhibition of melanin content, B16F10 cells were treated with 10, 50, 100, 200, and 400 $\mu \mathrm{g} / \mathrm{mL}$ CLE and induced by $500 \mu \mathrm{M}$ IBMX for $72 \mathrm{~h}$. The cells treated with IBMX showed significant increased melanin content compared to control (-). Medium of the cells were collected and its melanin content was analyzed by microplate reader at $405 \mathrm{~nm}$. The treatment of 50, 100, 200, and 400 $\mu \mathrm{g} /$ $\mathrm{mL}$ CLE significantly suppressed melanin accumulation of B16F10 (A). The changes of medium color were obtained using image scanner (B). Statistical analysis was performed at ${ }^{*} p<0.05,{ }^{* *} p<0.01$, and ${ }^{* * *} p<0.001$ by t-test. CLE, water extracts of Curcuma longa L.; IBMX, 3-isobutyl-1methylxanthine; Control (+), IBMX treated group without CLE; Control (-), IBMX and CLE untreated group.

(-), 멜라닌 형성을 유도하고 CLE를 처리하지 않은 B16F10 세포 는 control (+)로 표기하였다. 멜라닌 유도 기간 동안 평균 3 times/ day DMEM 배지를 갈아주었다. 유도가 끝난 후 B16F10 세포의 배 지에 용출된 멜라닌을 96-well plate에 $200 \mu \mathrm{L}$ 씩 넣어 microplate reader를 사용하여 $405 \mathrm{~nm}$ 의 흡광도에서 측정하여 CLE의 멜라닌 생성 저해 활성을 control (+)과 비교하여 평가하였다. 세포의 이미 지는 위의 $12-$ well plate를 CanoScan 9000F (Canon, Japan)으로 스캔하여 얻었다.

\section{RT-PCR을 통한 mRNA 발현수준 평가}

$\mathrm{CLE}$ 처리가 $\mathrm{HSFs}$ 의 콜라겐 형성과 피부탄력 증진에 관여하는 유전자 발현에 어떠한 긍정적인 영향을 주는지 알아보기 위해 RT$\mathrm{PCR}$ 을 통한 mRNA 발현수준을 분석하였다. HSFs 세포를 12-well plate에 $1 \times 10^{5}$ cells/mL의 농도로 $1 \mathrm{~mL}$ 씩 분주한 후, $10,100,200$, $400 \mu \mathrm{g} / \mathrm{mL}$ 농도의 CLE로 $2 \mathrm{~h}$ 동안 처리하였으며, TRLzol ${ }^{\circledR}$ 을 이용하 여 총 RNA를 추출하였다. TRIzol ${ }^{\circledR}$ 추출물에 $100 \mu \mathrm{L}$ 의 chloroform 을 넣은 뒤 $15 \mathrm{~s}$ 동안 잘 혼합하여, 17,000 rpm에서 $20 \mathrm{~min}$ 동안 원심 분리한 후 상층액을 획득하였다. 획득한 상층액에 $250 \mu \mathrm{L}$ 의 isopropanol을 넣고 $10 \mathrm{~min}$ 동안 상온에 방치한 다음 원심분리기
를 이용하여 $17,000 \mathrm{rpm}$ 에서 $15 \mathrm{~min}$ 동안 RNA를 분리하였다. AccuPower ${ }^{\circledR}$ CycleScript RT PreMix을 이용하여 분리된 RNA 는 정량한 뒤 $\mathrm{cDNA}$ 를 합성하였다. 또한 thermal cycler $\left(\mathrm{T} 100^{\mathrm{m}}\right.$; Bio-Rad Laboratories)를 이용하여 합성된 $\mathrm{cDNA}$ 는 RT-PCR을 수행한 후 mRNA 유전자 발현수준을 알아보기 위해 $2 \%(\mathrm{w} / \mathrm{v})$ 의 agarose gel에 $35 \mathrm{~min}$ 동안 전기영동 하여 유전자 발현을 분석하 였다. 본 실험에 이용된 primer sequences는 Table 1 와 같다. RT$\mathrm{PCR}$ 을 통한 RNA 발현수준을 평가한 것을 정량적으로 알기 위해 해당 밴드의 이미지 정량은 Image J 프로그램(National Institutes of Health, USA)을 사용하였다.

\section{5. 통계분석}

본 실험 결과의 데이터 통계는 3 회 반복 실험하여 평균 \pm 표준편 차를 이용하여 표현하였으며, Statistical Package for the Social Sciences (SPSS; BMM, USA) 프로그램을 이용하여 데이터 통계를 분석하였다. 각 그룹간의 유의성 정도를 평가하기 위해 일원배치 분산분석(one-way analysis of variance)법을 실시하였으며, 사후 검증은 대조군과의 유의성 차이를 검증하는 Student's t-test방법 을 통해 실시하였다 $(p<0.05)$.

Table 1. Primer sequences for RT-PCR analysis

\begin{tabular}{lll}
\hline Primer & Forward $\left(5^{\prime} \rightarrow 3^{\prime}\right)$ & Reverse $\left(5^{\prime} \rightarrow 3^{\prime}\right)$ \\
\hline Procollagen $1 \alpha 1$ & GTTGGGGGAGGGGTAGACAT & AGAGGCCAGATGACCCTTCA \\
Procollagen $1 \alpha 2$ & GCACCACTTGTGGCTTTTGA & TACCACACCAAACTGCCCTT \\
Elastin & GAGGTTGCCCAACCAAAAC & TCAGAGGGGACTGTTTCGGA \\
Actin beta & GCAGGAGTATGAGAGTCCG & AGGGACTTCCTGTAACAATGC \\
\hline
\end{tabular}

RT-PCR, reverse transcription-polymerase chain reaction. 


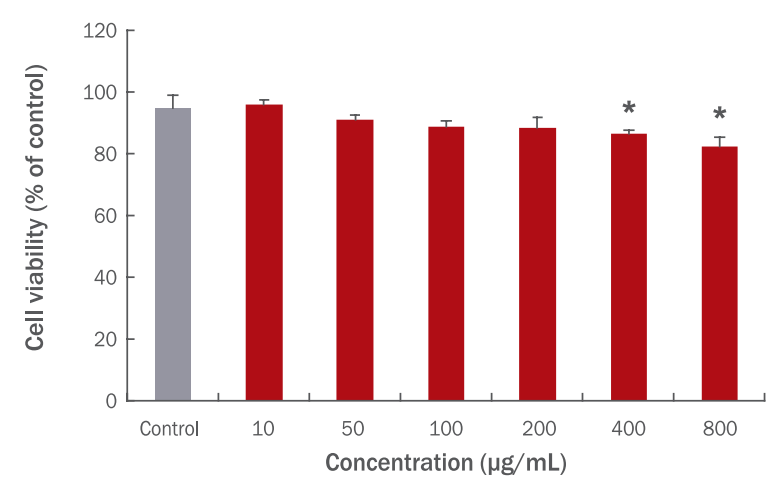

Figure 3. Effects of CLE on HSFs viability.

HSFs were treated with 10,50,100,200, 400, and $800 \mu \mathrm{g} / \mathrm{mL}$ CLE for $24 \mathrm{~h}$ and cell viability was evaluated by MTT assay at 570 $\mathrm{nm}$ using the microplate reader. The 400 and $800 \mu \mathrm{g} / \mathrm{mL}$ CLE significantly affected to the cell viability of HSFs. Further experiment was conducted under $400 \mu \mathrm{g} / \mathrm{mL}$ of CLE. Statistical analysis was performed at ${ }^{*} p<0.05$ by t-test. CLE, water extracts of Curcuma longa L.; Control, CLE untreated group; HSFs, human skin fibroblasts; MTT, thiazolyl blue tetrazolium bromide.

\section{Results and Discussion}

\section{B16F10에서 CLE의 세포독성 평가}

$\mathrm{B} 16 \mathrm{~F} 10$ 세포에서 $\mathrm{CLE}$ 의 세포독성을 평가하기 위하여 $\mathrm{MTT}$ assay를 실시하였다. B16F10 세포가 100\% 포화상태가 되었을 때, CLE를 $10,50,100,200,400,800 \mu \mathrm{g} / \mathrm{mL}$ 의 다양한 농도로 $24 \mathrm{~h}$ 동안 처리한 결과, $\mathrm{B} 16 \mathrm{~F} 10$ 세포의 생존율은 각각 $99.30 \%, 94.56 \%$, $97.80 \%, 79.08 \%, 86.43 \%, 75.92 \%$ 인 것으로 나타났다(Figure 1). $\mathrm{CLE} 200 \mu \mathrm{g} / \mathrm{mL}$ 과 $800 \mu \mathrm{g} / \mathrm{mL}$ 의 농도에서 유의적인 세포독성이 나타났으나, CLE $200 \mu \mathrm{g} / \mathrm{mL}$ 에서의 세포 생존율은 80\% 수준인 것 을 감안하여 이후 실험은 CLE를 $400 \mu \mathrm{g} / \mathrm{mL}$ 이하로 사용하였다.

\section{B16F10 세포에서 CLE의 멜라닌 생성 저해 활성}

$\mathrm{CLE}$ 가 B16F10 세포의 멜라닌 생성을 억제하는지 알아보기 위하 여 B16F10 세포가 70\% 포화상태 되었을 때, $500 \mu \mathrm{M} \mathrm{BBMX}$ 를 $72 \mathrm{~h}$ 동안 처리하여 멜라닌 형성을 유도하고 같은 기간 CLE를 10,50 , $100,200,400 \mu \mathrm{g} / \mathrm{mL}$ 의 유의적인 독성이 나타나지 않은 농도로 처리하였다. $\mathrm{B} 16 \mathrm{~F} 10$ 세포의 배지에 용출된 멜라닌 함량을 측정한 결과 CLE를 $10,50,100,200,400 \mu \mathrm{g} / \mathrm{mL}$ 의 농도로 처리하였을 때 control (+) 대비 멜라닌의 함량은 $64.28 \%, 20.69 \%,-3.22 \%$, $18.37 \%,-3.78 \%$ 인 것으로 나타났다. 특히 $50,100,200,400 \mu \mathrm{g} /$ $\mathrm{mL} \mathrm{CLE}$ 처리는 유의적으로 $\mathrm{B} 16 \mathrm{~F} 10$ 세포의 멜라닌 형성을 억제하 였다(Figure 2A).

$\mathrm{B} 16 \mathrm{~F} 10$ 세포에 축적된 멜라닌의 양을 이미지로 정성 분석하였을 때 위의 정량결과와 유사한 결과를 나타냈다. $\mathrm{BMX}$ 로 멜라닌 형성
을 유도하지 않은 control (-) 대비 IBMX를 처리하여 멜라닌을 유 도한 control (+)은 control (-)과 비교하여 다량의 멜라닌 형성이 관찰되었으며, CLE를 처리한 군에서는 control (+) 대비 멜라닌 함 량이 감소된 것을 색 변화로 확인할 수 있었다(Figure 2B).

본 실험결과는 CLE가 멜라닌 형성을 억제하여 화장품 및 식품 의 개발에 있어 효과적인 천연 미백소재로 활용될 수 있음을 시사 한다. 이전의 연구에 따르면 $1,000 \mu \mathrm{g} / \mathrm{mL}$ 울금의 에탄올 및 초임 계 추출물이 각각 $82.0 \%, 89.0 \%$ 의 높은 티로시나아제(tyrosinase) 저해 활성을 나타낸다고 보고하였다(An et al., 2006). 멜라닌 형성 과정에 있어 티로시나아제의 활성은 멜라닌 형성에 중요한 요소로 잘 알려져 있다(del Marmol et al., 1993). 따라서 본 실험에서 CLE 의 B16F10 세포에서 멜라닌 억제 활성은 티로시나아제 효소의 저 해에 의해 이뤄진 것으로 추측된다. 또한 Park et al. (2010)의 울금 추출물이 티로시나아제 저해 활성을 통해 멜라닌 형성을 억제할 수 있다는 선행연구는 본 실험의 결과를 뒷받침한다.

\section{HSFs에서 CLE의 세포독성 평가}

$\mathrm{HSFs}$ 세포에서 CLE의 세포독성을 평가하기 위하여 MTT assay 를 실시하였다. HSFs 세포가 $100 \%$ 포화상태가 되면 CLE를 10, $50,100,200,400,800 \mu \mathrm{g} / \mathrm{mL}$ 의 농도로 $24 \mathrm{~h}$ 동안 처리하였다. 그 결과 HSFs 세포의 생존율은 CLE를 처리하지 않은 대조군 대비 각각 $100.99 \%, 95.84 \%, 93.28 \%, 93.08 \%, 90.94 \%, 86.80 \%$ 로 나타 났다(Figure 3). HSFs에서 CLE $400 \mu \mathrm{g} / \mathrm{mL}$ 과 $800 \mu \mathrm{g} / \mathrm{mL}$ 농도에 서 유의적인 세포독성을 나타냈으며, 이후 실험에서는 $400 \mu \mathrm{g} / \mathrm{mL}$ 이하의 CLE를 사용하여 실험을 진행하였다.

\section{CLE 처리가 HSFs 세포의 procollagen1 $\alpha 1$, procollagen $1 \alpha 2$, elastin 발현에 미치는 영향}

피부의 결합조직 단백질 중에는 콜라겐이 가장 큰 비율로 존재 하며, 콜라겐 외에 엘라스틴과 같은 단백질이 존재하는 것으로 알 려져 있다(Kim et al., 2007). 새로이 합성되는 프로콜라겐은 fibrillogenesis 과정을 거치면서 콜라겐을 형성하게 되고 이로 인해 피부의 탄력을 구성하는데 기여하며, 또한 자외선에 의해 서 진피층의 콜라겐 및 엘라스틴 단백질의 감소를 유발하여 피 부의 탄력성 감소 및 주름 형성의 원인이 된다(Bateman et al., 1996; Houben et al., 2007). 진피는 대부분 fibroblasts로 구 성되어 있으며, 세포외기질(extracellular matrix, ECM)을 생 산하는 역할을 한다. 세포외기질에는 글리코스아미노글리칸 (glycosaminoglycan)과 히알루론산(hyaluronic acid) 등의 다당 류와 섬유상 단백질인 콜라겐, 엘라스틴 등이 존재한다. 따라서 본 연구에서는 CLE 처리가 피부조직의 형태를 유지하는 작용을 하는 콜라겐 및 피부조직의 탄력성과 관련성이 높은 엘라스틴 의 발현에 미치는 영향을 확인하였다. CLE를 HSFs에 10, 100, $200,400 \mu \mathrm{g} / \mathrm{mL}$ 의 농도로 $2 \mathrm{~h}$ 동안 처리한 후, procollagen1 
A
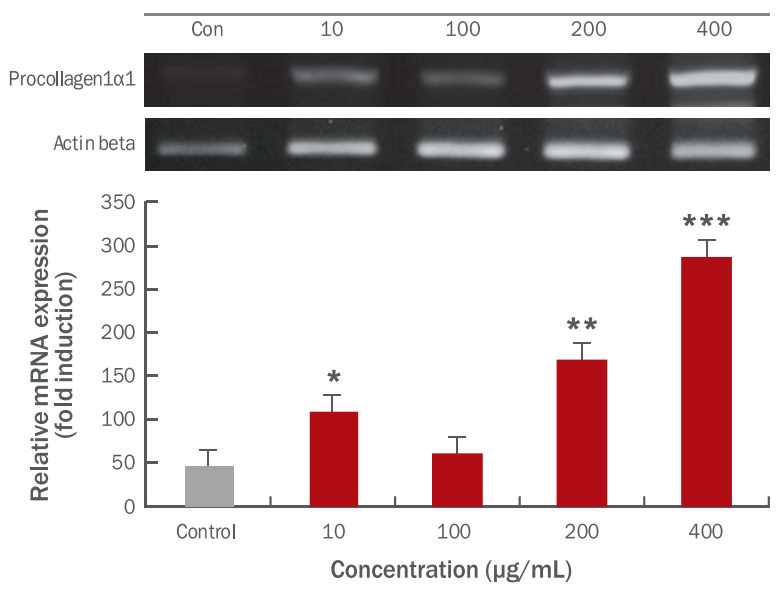

C
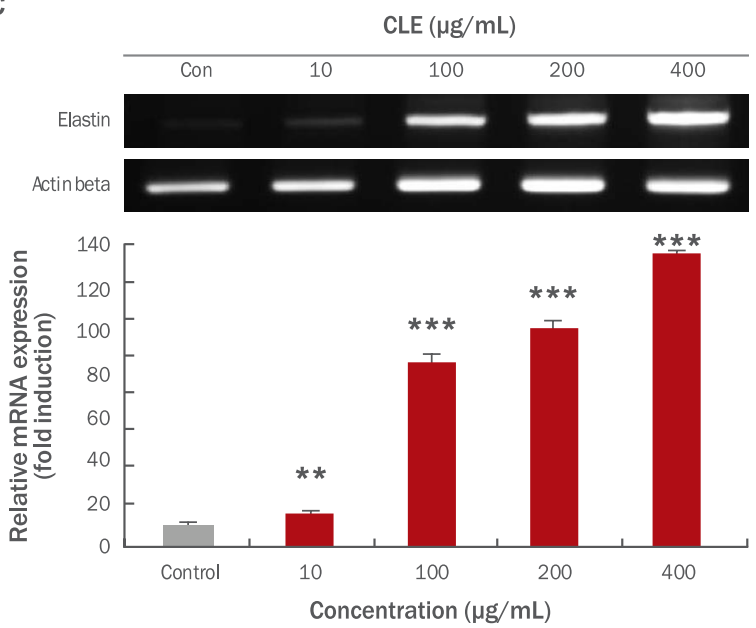

B
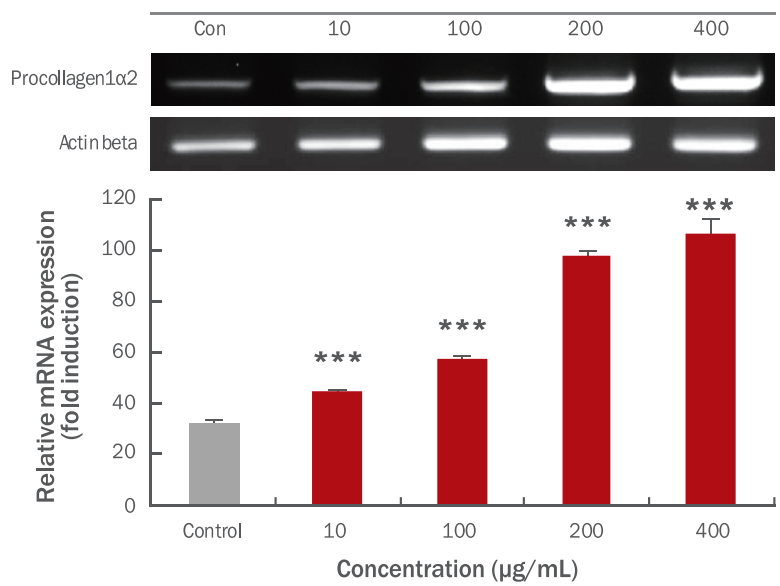

Figure 4. Effects of CLE on mRNA expression of skin fibril-related genes in HSFs.

The HSFs were exposed to the 10, 100, 200, and $400 \mu \mathrm{g} / \mathrm{mL}$ CLE for $2 \mathrm{~h}$. The mRNA expressions of skin fibril-related genes such as procollagen $1 \alpha 1(\mathrm{~A})$, procollagen $1 \alpha 2(\mathrm{~B})$, and elastin $(\mathrm{C})$ were examined by RT-PCR analysis. The CLE treatment between $10 \mathrm{and} 400 \mu \mathrm{g} / \mathrm{mL}$ up-regulated mRNA expressions of procollagen $1 \alpha 1$, procollagen $1 \alpha 2$, and elastin. Actin beta was used as a control. The mRNA expressions were quantified using Image J program. Each value of the graph corresponds to the percent concentrations divided by the amount of actin beta which is the control. Statistical analysis was performed at ${ }^{*} p<0.05,{ }^{* *} p<0.01$, and ${ }^{* * *} p<0.001$ by t-test. CLE, water extracts of Curcuma longa L.; Con, control (CLE untreated group); HSFs, human skin fibroblasts; RT-PCR, reverse transcription-polymerase chain reaction.

$\alpha 1$, procollagen $1 \alpha 2$, elastin의 발현 정도는 RT-PCR을 통해 분 석하였다. 그 결과, $\mathrm{CLE}$ 처리 농도가 증가할수록 $\mathrm{HSFs}$ 에서 procollagen $1 \alpha 1$, procollagen $1 \alpha 2$, elastin의 발현수준이 증가함 을 관찰하였다(Figure $4 \mathrm{~A}-\mathrm{C}$ ). 그러나 본 연구에서 CLE 처리를 통해 프로콜라겐 및 엘라스틴의 발현증가에 대한 명확한 기전은 확인하지 못했으므로, matrix metalloproteinases 활성 및 활성 산소종(reactive oxygen species)의 발생과 관련하여 CLE의 작 용기전에 대한 추가 실험이 요구된다. 이전의 연구에 따르면 콜 라겐 및 엘라스틴 펩타이드 혼합물 $(0.33 \%, \mathrm{w} / \mathrm{w})$ 식이를 10 주간 마우스가 섭취하였을 때 피부의 진피층에서 프로콜라겐의 합성이
유의적으로 증가하였으며, 이는 손상된 피부의 구조를 완화시 켜 주름발생과 피부의 탄력증진에 기여할 수 있다고 보고되었다 (Kim et al., 2009). 따라서, 본 연구에서의 CLE의 처리에 의한 procollagen1 $\alpha 1$, procollagen1 $\alpha 2$, elastin 유전자의 발현 증진은 진피층의 피부결합조직과 관련된 단백질인 콜라겐과 더불어 피 부의 탄력 증진에 도움을 줄 수 있음을 보여주는 결과라고 생각 된다. 


\section{Conclusion}

멜라닌은 외부의 자극에 대해 방어 작용으로 세포를 보호는 과정 에서 합성되며 종류와 양에 따라 피부의 색이 결정되고 피부를 보 호하는 긍정적인 역할을 한다. 하지만 과도하게 합성된 멜라닌은 색소침착, 주근깨, 피부염, 그리고 피부암 등을 유발하는 주요 원인 이 된다(Hill et al., 1997; Urabe et al., 1994). 최근 대중매체 등의 발달로 인해 사회적으로 미적인 아름다움에 대한 관심이 증가하고 깨끗하고 밝은 피부를 선호하게 되는 등 피부건강에 대한 관심이 증가하고 있다. 이를 바탕으로 다양한 기능성을 가진 화장품은 물 론 피부건강에 도움이 되는 식품, 즉 미용식품 관련 시장이 성장하 고 먹어서 피부를 건강하게 하려는 제품이 다양하게 개발되고 있다 (Davies, 1987; Fantone \& Ward, 1982; Yaar \& Gilchrest, 1998).

본 연구에서는 울금 물 추출물(CLE)을 사용하여 B16F10 세포에 서 멜라닌 생성 억제 활성을 통한 미백 활성을 평가하였으며, 또한 과도한 자외선으로 인해 주름이 생길 가능성이 있다는 보고에 따라 피부구조와 탄력에 연관성이 있는 procollagen1a1, procollagen1a2, elastin의 발현수준을 분석하기 위하여 HSFs를 활용하였다. 피부 의 멜라닌 형성 및 탄력 증진 효능 평가를 위하여 각각의 세포모델 에서 효능을 평가하였으며, 추후 $3 \mathrm{D}$ 세포모델 확립을 통해 추가적 인 흡수도 및 효능에 대한 검증이 요구된다. 또한 멜라닌 축적에 있 어 B16F10 melanoma 세포가 아닌 normal melanocytes 모델을 통 한 울금의 멜라닌 축적 억제 활성 역시 평가되어야 한다. 본 실험결 과 $\mathrm{B} 16 \mathrm{~F} 10$ 세포에서의 멜라닌 생성이 감소하였으며, 또한 $\mathrm{HSFs}$ 세 포에서의 procollagen $1 \alpha 1$, procollagen1 $\alpha 2$, elastin의 발현수준을 증 가시켰다. 따라서 CLE는 피부의 미백과 탄력에 효과를 줄 수 있는 소재로 활용될 수 있을 것이라 판단된다.

\section{Acknowledgements}

본 연구는 산업통상자원부와 한국산업기술진흥원의 "지역특화 산업육성사업”(과제번호 R0005174)으로 수행된 연구결과 입니다.

\section{References}

Ammon HP, Wahl MA. Pharmacology of Curcuma longa. Planta Medica, 57: 1-7, 1991.

An BJ, Lee JY, Park TS, Pyeon JR, Bae HJ, Song MA, Baek EJ, Park JM, Son JH, Lee CE, et al. Antioxidant activity and whitening effect of extraction conditions in Curcuma Ionga L. Korean Journal of Medicinal Crop Science, 14: 168-172, 2006.

Bateman JF, Lamandé SR, Ramshaw JA. Collagen superfamily. In: Extracellular matrix, volume 2. Comper WD (ed.), CRC
Press, Boca Raton, pp22-67, 1996.

Baumann L. Skin ageing and its treatment. The Journal of Pathology, 211: 241-251, 2007.

Brenneisen P, Sies H, Scharffetter-Kochanek K. Ultraviolet-B irradiation and matrix metalloproteinases: from induction via signaling to initial events. Annals of the New York Academy of Sciences, 973: 31-43, 2002.

Chung JH. Photoaging in Asians. Photodermatology, Photoimmunology \& Photomedicine, 19: 109-121, 2003.

Davies KJ. Protein damage and degradation by oxygen radicals: I . general aspects. The Journal of Biological Chemistry, 262: 9895-9901, 1987.

del Marmol V, Ito S, Jackson I, Vachtenheim J, Berr P, Ghanem G, Morandini R, Wakamatsu K, Huez G. TRP-1 expression correlates with eumelanogenesis in human pigment cells in culture. FEBS Letters, 327: 307-310, 1993.

Elias PM. Epidermal lipids, barrier function, and desquamation. Journal of Investigative Dermatology, 80: 44s-49s, 1983.

Fantone JC, Ward PA. Role of oxygen-derived free radicals and metabolites in leukocyte-dependent inflammatory reactions. The American Journal of Pathology, 107: 395418, 1982.

Feingold KR, Schmuth M, Elias PM. The regulation of permeability barrier homeostasis. Journal of Investigative Dermatology, 127: 1574-1576, 2007.

Fisher GJ, Kang S, Varani J, Bata-Csorgo Z, Wan Y, Datta $\mathrm{S}$, Voorhees JJ. Mechanisms of photoaging and chronological skin aging. Archives of Dermatology, 138: 1462-1470, 2002.

Fisher GJ, Wang ZQ, Datta SC, Varani J, Kang S, Voorhees $\mathrm{JJ}$. Pathophysiology of premature skin aging induced by ultraviolet light. The New England Journal of Medicine, 337: 1419-1428, 1997.

Hill HZ, Li W, Xin P, Mitchell DL. Melanin: a two edged sword? Pigment Cell \& Melanoma Research, 10: 158-161, 1997.

Houben E, De Paepe K, Rogiers V. A keratinocyte's course of life. Skin Pharmacology and Physiology, 20: 122-132, 2007.

Ito S, Itoga K, Yamato M, Akamatsu H, Okano T. The coapplication effects of fullerene and ascorbic acid on UV-B irradiated mouse skin. Toxicology, 267: 27-38, 2010.

Kim B, Choi YE, Kim HS. Eruca sativa and its flavonoid components, quercetin and isorhamnetin, improve skin barrier function by activation of peroxisome proliferator- 
activated receptor (PPAR)- $\alpha$ and suppression of inflammatory cytokines. Phytotherapy Research, 28: 1359-1366, 2014.

Kim JK, Lee JH, Yang MS, Seo DB, Lee SJ. Beneficial effect of collagen peptide supplement on anti-aging against photodamage. Korean Journal of Food Science and Technology, 41: 441-445, 2009.

Kim N, Koo B, Lee S, Hwang E, So S, Do J. Effect of Korean red ginseng on collagen biosynthesis and MMP-I activity in human dermal fibroblast. Journal of Ginseng Research, 31: 86-92, 2007.

Park EY, Hur SJ, Kim KY, Whang WK, Yang KS. Anti-oxidant and whitening effects of Curcuma longa L. Asian Journal of Beauty and Cosmetology, 8: 111-120, 2010.

Revathy S, Elumalai S, Benny M, Antony B. Isolation, purification and identification of curcuminoids from turmeric (Curcuma longa L.) by column chromatography. Journal of Experimental Sciences, 2: 21-25, 2011.

Rittié L, Fisher GJ. UV-light-induced signal cascades and skin aging. Ageing Research Reviews, 1: 705-720, 2002.

Royer M, Prado M, García-Pérez ME, Diouf PN, Stevanovic T. Study of nutraceutical, nutricosmetics and cosmeceutical potentials of polyphenolic bark extracts from Canadian forest species. PharmaNutrition, 1: 158-167, 2013.

Seite S, Zucchi H, Septier D, Igondjo-Tchen S, Senni K, Godeau G. Elastin changes during chronological and photoageing: the important role of lysozyme. Journal of the European Academy of Dermatology and Venereology, 20: 980-987, 2006.
Shephard P, Martin G, Smola-Hess S, Brunner G, Krieg T, Smola H. Myofibroblast differentiation is induced in keratinocyte-fibroblast co-cultures and is antagonistically regulated by endogenous transforming growth factor- $\beta$ and interleukin-1. The American Journal of Pathology, 164: 2055-2066, 2004.

Shon MS, Kim GN. Anti-oxidant and anti-obese activities of turmeric (Curcuma longa L.) extract in 3T3-L1 cells. Asian Journal of Beauty and Cosmetology, 12: 169-175, 2014.

Urabe K, Aroca P, Tsukamoto K, Mascagna D, Palumbo A, Prota G, Hearing VJ. The inherent cytotoxicity of melanin precursors: a revision. Biochimica et Biophysica Acta (BBA)-Molecular Cell Research, 1221: 272-278, 1994.

Wenk J, Brenneisen P, Meewes C, Wlaschek M, Peters T, Blaudschun R, Ma W, Kuhr L, Schneider L, ScharffetterKochanek K. UV-induced oxidative stress and photoaging. Current Problems in Dermatology, 29: 83-94, 2001.

Yaar M, Gilchrest BA. Aging versus photoaging: postulated mechanisms and effectors. Journal of Investigative Dermatology Symposium Proceedings, 3: 47-51, 1998. 


\section{국문초록}

\section{울금 추출물의 피부미용식품 소재로서의 기능성 평가}

주형진 ${ }^{1}$, 이성애 ${ }^{1}$, 김령현 $^{1}$, 박부덕$^{2}$, 김교남 ${ }^{1 *}$

${ }^{1}$ 경남대학교 식품영양생명학과, 경상남도 창원시, 한국

${ }^{2}$ 발효촌, 경상북도 경산시, 한국

목적: 생강과에 속하는 다년생 초본식물 울금(Curcuma longa L.)에 대한 항산화 및 항암 등의 연구가 비교적 다수 수행되었으 나, 피부건강과 관련한 연구는 상대적으로 미미한 실정이다. 따라서, 본 연구에서는 국내 진도산 울금 물 추출물(water extracts of Curcuma longa L., CLE)의 B16F10 세포에서 멜라닌 생성 저해 활성 및 human skin fibroblasts (HSFs)에서 피부 섬유구조관 련 유전자의 발현조절에 미치는 영향을 분석하여 울금 추출물의 미용기능식품 및 화장품 소재로서의 가능성을 평가하고자 하였다. 방법: B16F10, HSFs에서 CLE의 세포독성은 thiazolyl blue tetrazolium bromide (MTT) assay로 평가하였다. B16F10 세포에서 CLE의 멜라닌 생성 저해 활성은 세포의 배지에 용출된 멜라닌의 정량과 이미지 분석을 실시하였다. CLE가 HSFs 세포의 피부 섬 유구조 관련 유전자의 발현에 미치는 영향은 reverse transcription-polymerase chain reaction (RT-PCR) 분석법을 통해 평가 하였다. 결과: MTT assay를 통해 CLE의 농도는 B $16 \mathrm{~F} 10$ 및 $\mathrm{HSFs}$ 세포에서 $400 \mu \mathrm{g} / \mathrm{mL}$ 이하로 결정하였다. B16F10 세포에서 50, $100,200,400 \mu \mathrm{g} / \mathrm{mL}$ 의 CLE 처리는 유의적으로 멜라닌 형성을 억제하였다. 또한 HSFs에서 $10,100,200,400 \mu \mathrm{g} / \mathrm{mL}$ 의 농도로 $\mathrm{CLE}$ 를 처리한 결과 procollagen $1 \alpha 1$, procollagen $1 \alpha 2$, elastin의 mRNA 발현수준을 현저히 증가시켰다. 결론: 본 연구결과는 CLE를 이용하여 미백 및 피부섬유관련 유전자의 상향조절로 인한 피부탄력 증진에 효과가 있음을 확인하였으며 이후 미용기능식품 및 화 장품 소재로서 충분히 활용될 수 있음을 시사한다.

핵심어: 울금, 피부, 멜라닌, 탄력, 미용식품

본 연구는 산업통상자원부와 한국산업기술진흥원의 “지역특화산업육성사업”(과제번호 R0005174)으로 수행된 연구결과 입니다.

\section{참고문헌}

김정기, 이지해, 양미숙, 서대방, 이상준. 콜라겐 펩타이드의 피부 광노화 예방 효과. 한국식품과학회지, 41: 441-445, 2009. 박은영, 허선정, 김경영, 황완균, 양기숙. 울금의 항산화 및 미백효과. 아시안뷰티화장품학술지, 8: 111-120, 2010.

손명수, 김교남. 3T3-L1 세포에서 울금(Curcuma longa L.) 추출물의 항비만 및 항산화 활성. 아시안뷰티화장품학술지, 12 : 169-175, 2014.

안봉전, 이진영, 박태순, 편정란, 배호정, 송미애, 백은지, 박정미, 손준호, 이창언, 등. 추출조건에 따른 울금의 항산화 및 미 백 효과. 한국약용작물학회지, 14: 168-172, 2006. 


\section{中文摘要}

\section{姜黄提取物作为皮肤美容食品原料的功效性评价}

朱亨眞 ${ }^{1}$, 李成愛 $^{1}$, 金伶炫 $^{1}$, 朴富德 $^{2}$, 金㚁男 $^{1 *}$

${ }^{1}$ 庆南大学食品营养生命学科, 庆尚南道昌原市, 韩国

2发酵村, 庆尚北道庆山市, 韩国

目的: 姜黄 (Curcuma longa L.) 属于生姜科的多年草本植物, 虽然对姜黄的抗氧化以及抗癌的先行研究比较多, 但皮肤 健康相关的研究显然非常少。因此，利用韩国国产姜黄水提取物（water extracts of Curcuma longa L., CLE），在B16F10 细胞中探讨黑色素抑制活性 ; 在人皮肤成纤维细胞 (human skin fibroblasts, HSFs) 中, 探讨皮肤纤维相关基因的调 控作用, 鉴定CLE的美容功效性食品和化妆品原料的应用可行性。方法: 在B16F10和HSFs细胞中CLE的细胞毒性, 利用 thiazolyl blue tetrazolium bromide (MTT) assay法来评价。在B16F10细胞中, CLE的黑色素抑制活性, 通过细胞培养 基中洗脱的黑色素含量和图像分析来进行测定。为鉴定CLE对皮肤纤维相关基因的调控作用，通过 reverse transcriptionpolymerase chain reaction（RT-PCR）方法来评价。结果: 在B16F10和HSFs细胞中, 利用MTT assay法确定CLE以后实验 中采用浓度为 $400 \mu \mathrm{g} / \mathrm{mL}$ 以下。在B16F10中，CLE分别以50、100、200、400 $\mu \mathrm{g} / \mathrm{mL}$ 浓度处理时，明显抑制黑色素形成。 在HSFs细胞中, CLE分别以 $10 、 100 、 200 、 400 \mu \mathrm{g} / \mathrm{m}$ 的浓度处理时, 其结果显示： procollagen1a1、procollagen1a2、 elastin的mRNA表达水平具有浓度依赖性显著增加。结论：通过研究，鉴定了CLE具有美白效能以及对皮肤纤维相关基因 的调控，具有增加皮肤弹力的效能。因此将来，CLE作为美容功效性食品和化妆品原料充分具有可行性。

关键词: 姜黄, 皮肤, 黑色素, 弹力, 美容食品 